\title{
Health Risks in Natural Disasters: Four Case Studies in the Philippines
}

\author{
Exaltacion E. Lamberte ${ }^{1}$, Feorillo Petronillo A. Demeterio $\mathrm{III}^{2}$, and Wilfred Luis L. Clamor ${ }^{3}$
}

${ }^{1,2,3}$ De La Salle University, Manila, Philippines

\section{Article history:}

Submitted: 31 March 2021

Revised: 8 June 2021

Accepted: 15 June 2021

\section{Keywords:}

Disaster risk reduction

Disaster preparedness

Health risks

Case studies

Philippines
ABSTRACT. The Philippines is prone to a variety of natural calamities. Consequently, the community's health is impacted by many extreme events. This study investigates stakeholders' knowledge and preparedness in the face of major natural events and disasters, health impacts of disasters in the community, and different sectors' response amid extreme events, explicitly flooding, earthquakes, super typhoons, and volcanic eruptions. Data was gathered from four locations through interviews and focus group discussions, and available literature and situation reports. According to the narratives, residents' and local government units' awareness of an impending catastrophic event and disaster preparations are critical. Moreover, community members experienced various immediate, shortterm, and long-term health impacts due to various disasters. Therefore, the lessons in this study should be used to improve its preparations, strategies, and protocols.

\subsection{Introduction}

The Philippines is vulnerable to extreme disasters due to being in the Ring of Fire and the Pacific Typhoon Belt. As a result, different parts of the country experienced various forms of disasters based on geographical location and characteristics, such as Cagayan de Oro, Tacloban, Legazpi, and the Municipality of Tubigon. (National Disaster Risk Reduction Management Council [NDRRMC], 2012). This research focuses on flooding, earthquake, super typhoon, and volcano. Specifically, this will compare situations in the Cagayan de Oro City, Tacloban, Legazpi, and Tubigon Municipality. In addition, this research also investigated the effects of catastrophes on the health of the afflicted people and the actions of various sectors in the face of several catastrophic occurrences.

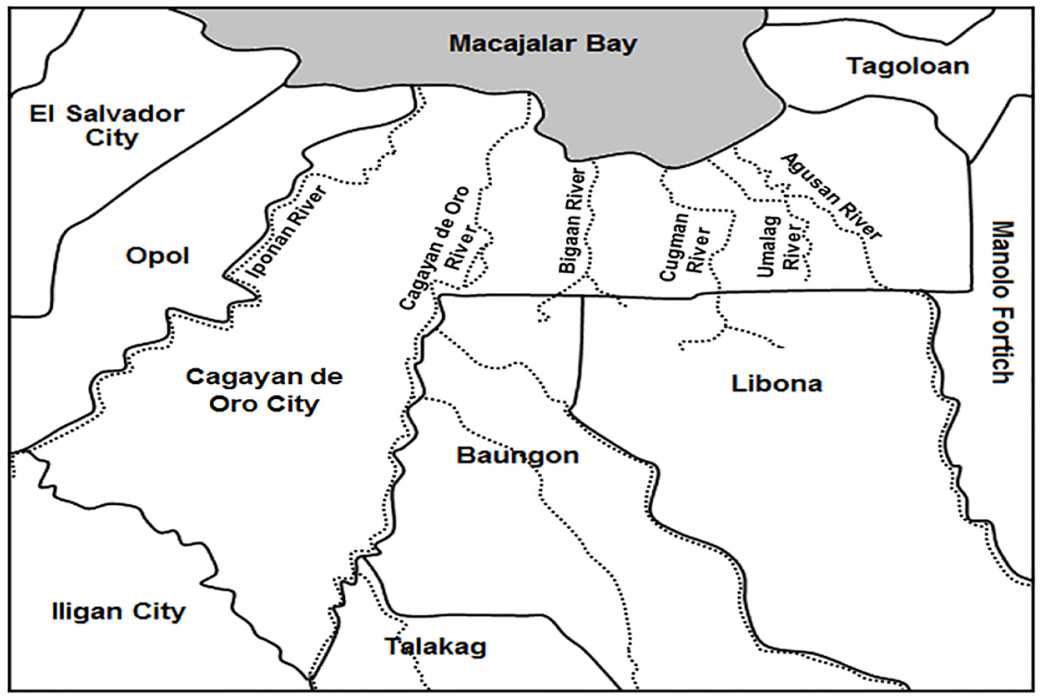

Figure 1. The Six Major River Systems of Cagayan de Oro

Cagayan de Oro City has more than six hundred thousand inhabitants and is situated the Northern Mindanao coast. It serves as the capital of the province of Misamis Oriental. Different rivers such as Iponan, Agusan, and so on all pour into Macajalar Bay in this city, as seen in Figure 1. 
Three typhoons (Washi, Bopha, \& Tembin) swept in Mindanao in 2011, 2012, and 2017, respectively. Although the core pathways of the typhoons did not immediately pass over the mentioned city, the heavy rain by these typhoons flooded Cagayan de Oro city. This study analyzes the flooding occurrence in Cagayan de Oro City, which is caused by this tropical cyclone. This study will focus on the occurrence of Washi as the most destructive typhoon experienced by the city.

On December 15, 2011, Typhoon Washi reached the south-eastern part of the Philippines. It made landfall in areas near Surigao del the next day. It brought severe rainfall to the area as it traveled diagonally over the island of Mindanao.

On December 17, 2011, floods occurred in the mentioned city, notably in the vicinity of different rivers. The rushing waves in the city damaged more than twelve thousand homes and destroyed more than seven thousand others. The death toll reached more than six hundred individuals because of drowning. In addition, tropical Storm Washi rendered 10 of the city's approximately 50 barangay health clinics inoperable. The floods impacted half of all the barangays in the city. These flooded regions are home to more than thirty thousand families or more than two hundred thousand individuals (NDRRMC, 2012).

Tubigon Municipality is at the northwest shore of Bohol. As of 2015, the municipality has a population of 45,893 . It is one of the municipalities having a very large population on the island. The recently found North Bohol Fault runs across the southern part of Tubigon Municipality, as seen in Figure 2. Furthermore, Figure 2 also depicts Tubigon Municipality's proximity to the different fault lines in the island of Bohol

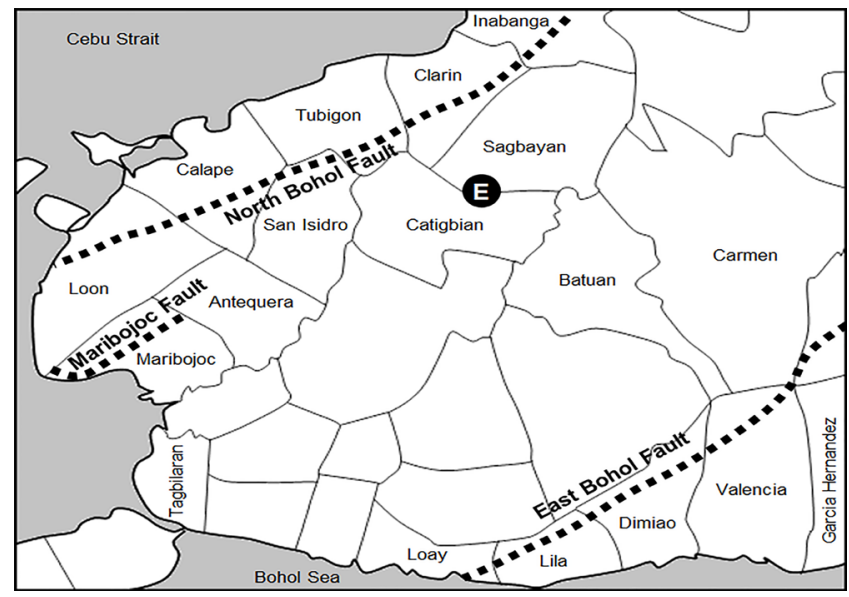

Figure 2. Faults near the Municipality of Tubigon

In the early hours of October 15,2013 , a significant earthquake shook various islands in the Visayas. In the Municipality of Tubigon, the quake killed 11 people and wounded 96 others. It destroyed 1,674 homes and partially destroyed 5,249 others. It impacted all 34 barangays and nearly all of its inhabitants (NDRRMC, 2014b).

Tacloban City has a population of more than two hundred thousand people is part of Leyte near the strait of San Juanico. Also, Tacloban is the city capital of Leyte. Figure 3 depicts the areas that were vulnerable due to surges. An example of an occurrence is the typhoon Haiyan. Haiyan reached the Philippines on November 7, 2013, with winds of 285 kilometers per hour. This typhoon was one of the strongest and deadliest typhoons that reached the Philippine Islands. It is the most violent storm to have hit the Philippine Islands. Although the central route of this super typhoon did not go through Tacloban, it produced a storm surge in various places in the city. The super typhoon swept through the areas within the city, causing a calamity that disfigured the same town as the super typhoon's most brutally affected community. It left 2,646 people dead and 701 people missing in the city. It wreaked havoc on all 138 barangays of Tacloban City, specifically through buildings or infrastructures (NDRRMC, 2014a). 


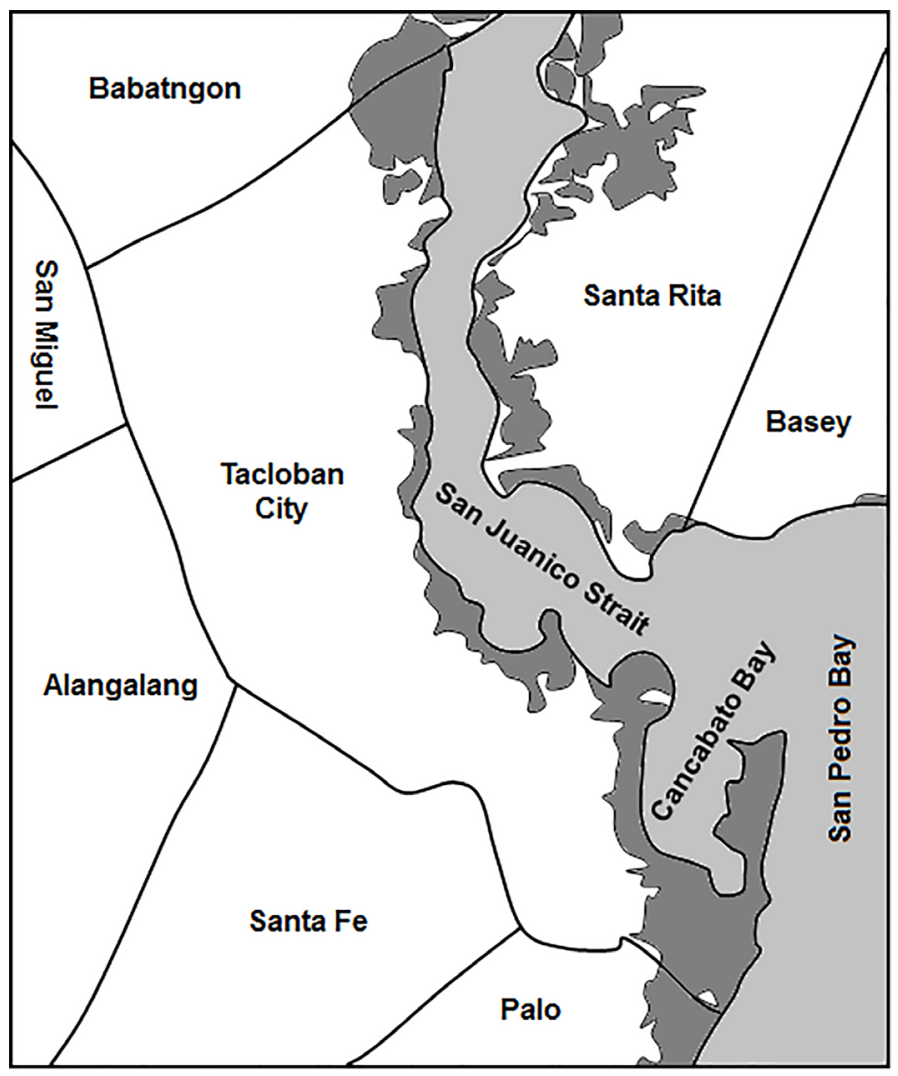

Figure 3. Flooding in the City of Tacloban

As of 2015, the population of Legazpi City was 196,639 people. This city is part of Albay Gulf. It serves as the capital of the Albay province in Bicol. Figure 4 depicts the areas of Legazpi City sharing Mayon Volcano's geographical boundaries with various towns and cities in the area. In addition, figure 4 depicts how Legazpi City is affected by the hazardous areas of the Mayon.

This volcano is famous due to its picturesque features, but it is also the most active and dangerous volcano. Since 1666, there have been over fifty reported eruptions. Its most devastating explosion occurred in 1814, killing 1,200 people and destroying an 18th-century Franciscan church, resulting in the now-famous Cagsaua Ruins. Its most recent eruption, in 1993, was the most catastrophic, resulting in the deaths of 77 people.

Although the eruption in 2006 did not produce any forms of mortalities, the lahar floods generated by a particular Typhoon during that year resulted in several deaths that exceeded the disaster during the year 1814 (Orense \& Ikeda, 2007). This study analyzes the experiences of the city through its most recent eruption.

For this volcano, the Philippine Institute of Volcanology and Seismology (PHIVOLCS) maintains a particular system of alarming residents. The alarm system of PHIVOLCS has been in existence since 2014 in its current configuration. In September 2016, a level 1 alert signal was issued. After that, authorities upped the alert to level 4 , triggering the mandatory evacuation process. For more than a month, alert level 4 was raised until the first week of March 2018, when alert level 3 was announced (PHIVOLCS, 2018). 


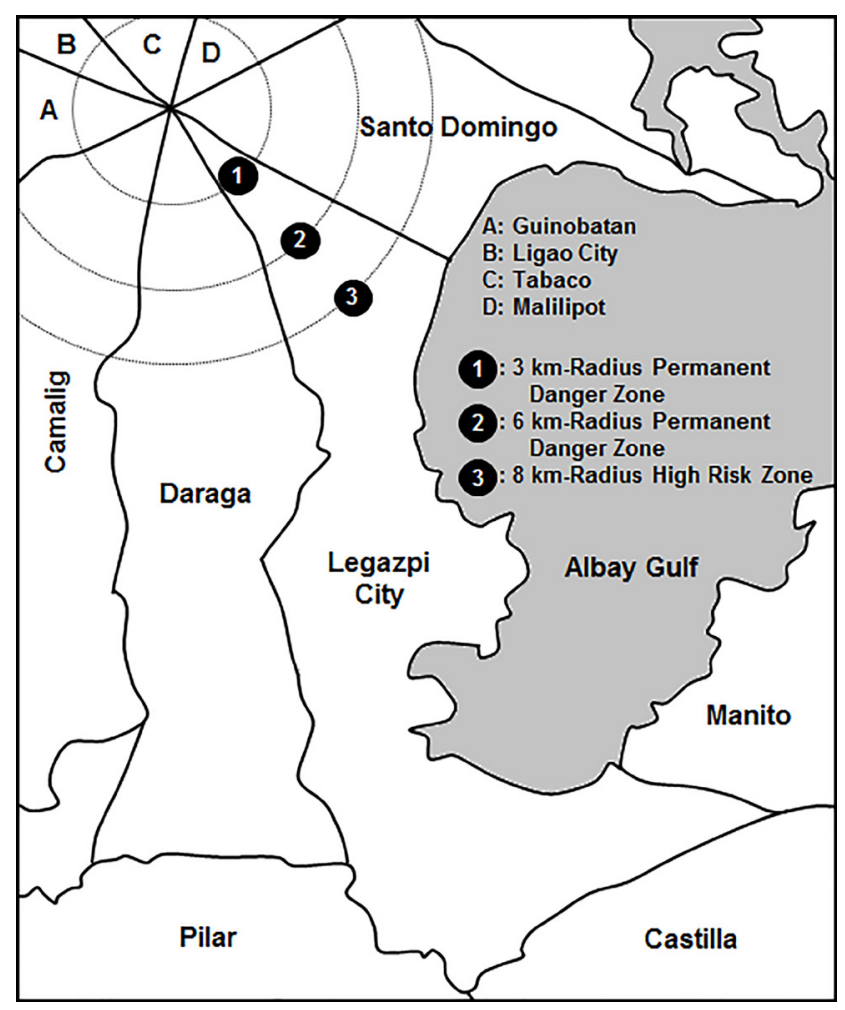

Figure 4. High-Risk Zones of Mayon Volcano in the City of Legazpi

\subsection{Research Objectives}

This research examines stakeholders' knowledge and preparedness for extreme natural occurrences and disasters, the health effects of catastrophes in the community, and the responses of various sectors in the aftermath.

Specifically, this study answers the following questions:

1. How well prepared are stakeholders for catastrophic natural disasters and harsh weather?

2. What are the term health risks of the extreme natural occurrences that occurred in the indicated areas?

3. How do these health risks vary based on the catastrophes mentioned?

4. How do the affected areas perceive their effectiveness in handling the health consequences of extreme natural disasters?

\subsection{Methods}

This report was created as a result of qualitative research that used a descriptive-comparative case study approach. This method allows the researcher to explain and compare the similarities, contrasts, and patterns found inside and between instances from various contexts. (Goodrick, 2014). Moreover, this study uses the phenomenological approach in the interviews and FGDs. This approach describes the lived experiences and encounters that depend on informants and participants' conscious activities (Dreher \& Santos, 2017).

Interviews, FGDs, secondary data collecting in the research locales, and data harvesting from various works of literature and situation reports were all part of the data collecting process. This study used purposive sampling in choosing the participants of the study. Most were survivors, local government unit officials, and health practitioners. 
The researchers transcribed the informants' narratives and arranged and organized the data to answer the research questions. Content analysis was performed to evaluate the data in this study, which was done through a review of the transcripts. Data were examined and organized based on the informants' and discussants' narratives.

\subsection{Results and Discussion}

\section{Disaster knowledge and preparedness}

Cagayan de Oro City. The fact that Mindanao is part of the Pacific Typhoon Belt has various major repercussions due to the severity of Washi in Cagayan de Oro City. According to interviewees, the communities of the mentioned city and, more broadly, the whole island of Mindanao had a false feeling of security in the face of deadly weather disturbances. According to the informants and even works of literature, inhabitants perceive that storms generally move through the center and upper regions of the Philippines (Franta et al., 2016). Moreover, in general, residents of the city had no prior experience with significant floods. They had no idea how to prepare for such natural disasters. Also, in 2010, the politicians of this city embarked on housing projects that entailed the inexpensive distribution of government-owned lands. However, the housing projects are primarily based in hazard zones. Another implication is that the city's local government unit did not pay attention to maps presenting risks along the river basins of the city. Lastly, its local government does not have a council on disaster risk reduction during the event. Hence, its local government did not have any preventive measures amid Tropical Storm Washi (Franta et al., 2016).

Tubigon Municipality. Significant earthquakes have struck the island province of Bohol in recent years. A magnitude of 6.8 in 1990 and a magnitude of 5.6 in 1996 are two examples. The island province mentioned earlier province is likewise firmly inside the typhoon belt's path. According to the literature, individuals on the island completed disaster preparedness training in 2008 (La Viña \& Berse, 2013). With that, with the help of local government units, individuals have constructed a seismic hazard map in that same year. The segment of the map is depicted in Figure 4. This also presents the fault lines near the area.

The Provincial Disaster Risk Reduction and Management Council was founded and recognized in 2011 in the aforementioned island province. Tubigon Municipality, it is fair to suppose, had a DRRM council at the same time. However, there were some issues highlighted based on the interviews and documents. The first is a danger map for Bohol. According to local government unit informants, the North Bohol Fault was still unknown when the map was created. According to the informants, only approximately a quarter of the municipality was very vulnerable to earthquake risks. However, the informants classified about $34 \%$ of the entire island province as being extremely vulnerable. Thus, even if the municipality properly implemented a danger map in 2008, the 2013 earthquake would still cause devastation.

The second is about the National Building and National Structural Codes, both of which were updated in 2010. Even if Tubigon Municipality wholly followed such rules, a large portion of the city's developed structures would remain susceptible. This risk arises from the development of buildings or facilities before 2010, many of which have infrastructural flaws (La Viña \& Berse, 2013). Is the municipality requiring that its structures be converted to meet the National Building and National Structural Codes criteria as of 2010? This proposal seems improbable, given the loss of its historic cathedral and the collapse of its Spanish-era municipal hall, which revealed its absence of reinforcing steel bars.

Tacloban City. The city of Tacloban was expected as the model of national disaster preparedness several years before the catastrophe of the super typhoon hit the area. Furthermore, Tacloban was even awarded the best disaster preparedness by a particular organization (City of Tacloban, 2016). Even though Tacloban City had previously undergone at least two severe storm surges, one in 1897 and the other in 1912, the current residents were unaware of these disasters. According to tales and literature, people in Tacloban City have no live recollection of storm surges (Luces, 2013). However, even if communities know storm surges, there would still be multiple deaths, according to Neussner's (2014) assessment. The current storm surge hazard map was shown to be grossly underestimating the amount of water that may enter the city. 
Adverse effects happened due to issues of the city in recognizing the effects of the super typhoon. First, Tacloban did not implement a required preventive evacuation plan. Only 738 households, or 3,015 people, were proactively put in four evacuation facilities, according to NDRRMC (2014a). Second, several sections of the city have designated evacuation shelters in areas that will be immediately impacted by the storm surge (Neussner, 2014).

Legazpi City. Mayon Volcano has previously erupted several times in recorded history. The catastrophe that it has caused is imprinted on the minds and legends of communities. The understanding and experiences of inhabitants of such tragedies, when combined with the Philippine Institute of Volcanology and Seismology's (PHIVOLCS) continuous scientific observation, wellarticulated warning system, and Albay Public Safety and Emergency Management Office's (APSEMO) reactive approaches lead to a remarkable level of preparedness of the city on various extreme events or disasters. In addition, PHIVOLCS has constructed a series of comprehensive maps of Mayon Volcano and the surroundings of the area, detecting or depicting various hazards (i.e., lahar, lava, and pyroclastic flow) (PHIVOLCS, 2017). These maps are used by the DRRM councils of local government entities. The efforts of APSEMO, Albay Province's DRRM council, and DRRM councils of the municipalities resulted in a high degree of preparedness among communities on disasters.

\section{Disaster health problems}

This section describes the community's health concerns, which are grouped as injuries, infectious illnesses, non-communicable illnesses, and psycho-social difficulties, and are impacted by time. Interviews, discussion points, disaggregated World Health Organization records, and earlier literature were used to compile the data. (World Health Organization [WHO], 2013; McCall, 2014; Ballera et al., 2015; Czaicki et al., 2015; Curato, 2018).

Table 1 compares the four scenarios in terms of the immediate health impact on the affected population. Physical issues, non-communicable diseases, and psycho-social issues are all predicted direct outcomes of extreme natural catastrophes on the affected population.

Table 1. Immediate health impact of disasters

\begin{tabular}{|c|c|c|c|}
\hline $\begin{array}{l}\text { Extreme } \\
\text { Event }\end{array}$ & Physical Issues & $\begin{array}{c}\text { Non-Communicable } \\
\text { Diseases }\end{array}$ & $\begin{array}{c}\text { Psycho-social } \\
\text { Issues }\end{array}$ \\
\hline Flooding & $\begin{array}{l}\text { Drowning } \\
\text { Physical Injuries (i.e., Open } \\
\text { Wounds, Bruises) }\end{array}$ & & $\begin{array}{l}\text { Psycho-social } \\
\text { Stress }\end{array}$ \\
\hline Earthquake & $\begin{array}{l}\text { Physical Injuries (i.e., Cerebral } \\
\text { Concussions, Trauma) }\end{array}$ & $\begin{array}{l}\text { Heart Diseases } \\
\text { and Abnormalities } \\
\text { (i.e., Hypertension, } \\
\text { Cardiogenic Shock) }\end{array}$ & $\begin{array}{l}\text { Psycho-social } \\
\text { Stress }\end{array}$ \\
\hline $\begin{array}{l}\text { Super } \\
\text { Typhoon }\end{array}$ & $\begin{array}{l}\text { Physical Injuries (i.e., Bruises) } \\
\text { Skin Problems (i.e., Irritation } \\
\text { Drowning }\end{array}$ & $\begin{array}{l}\text { Heart Diseases and } \\
\text { Abnormalities (i.e., } \\
\text { Hypertension) }\end{array}$ & $\begin{array}{l}\text { Psycho-social } \\
\text { Stress }\end{array}$ \\
\hline $\begin{array}{l}\text { Volcanic } \\
\text { Eruption }\end{array}$ & $\begin{array}{l}\text { Physical Injuries (i.e., Open } \\
\text { Wounds, Bruises) } \\
\text { Eye Problems (i.e., Irritation) } \\
\text { Skin Problems (i.e., Irritation }\end{array}$ & $\begin{array}{l}\text { Respiratory Issues (i.e., } \\
\text { trouble breathing) }\end{array}$ & $\begin{array}{l}\text { Psycho-social } \\
\text { Stress }\end{array}$ \\
\hline
\end{tabular}

Table 2 shows the short-term health effects of disasters and their comparison in the four cases of disasters in the country. Extreme natural disasters have a short-term health impact, resulting in a slew of instances. Some of these episodes are sparked by the immediate health consequences of various disasters mentioned. Other instances arose due to the aftermath of extreme events such as having open wounds due to the removal of debris, dermatological issues and leptospirosis due to flooding, and diarrhea due to issues of having a clean water supply. Other psycho-social issues are caused in the evacuation centers, such as mental health issues and even risky health behaviors 
Table 2. Short-term health impact of disasters

\begin{tabular}{|c|c|c|c|c|}
\hline $\begin{array}{l}\text { Extreme } \\
\text { Event }\end{array}$ & Physical Issues & $\begin{array}{l}\text { Communicable } \\
\text { Diseases }\end{array}$ & $\begin{array}{l}\text { Non-Communicable } \\
\text { Diseases }\end{array}$ & $\begin{array}{l}\text { Psycho-social } \\
\text { Issues }\end{array}$ \\
\hline Flooding & $\begin{array}{l}\text { Physical Injuries } \\
\text { (i.e., Open } \\
\text { Wounds, Bruises) } \\
\text { Eye Problems (i.e., } \\
\text { Irritation) }\end{array}$ & $\begin{array}{l}\text { Dermatological Issues } \\
\text { Fever } \\
\text { Measles } \\
\text { Coughs and Colds } \\
\text { Chicken Pox } \\
\text { Typhoid fever } \\
\text { Respiratory Diseases }\end{array}$ & $\begin{array}{l}\text { Asthma } \\
\text { Acute Malnutrition } \\
\text { Tetanus } \\
\text { Leptospirosis } \\
\text { Diarrhea } \\
\text { Acute Hemorrhagic } \\
\text { Fever } \\
\text { Dengue }\end{array}$ & $\begin{array}{l}\text { Psycho-social } \\
\text { Stress (i.e., mental } \\
\text { health issues, } \\
\text { drinking behaviors, } \\
\text { risky health } \\
\text { behaviors) }\end{array}$ \\
\hline Earthquake & $\begin{array}{l}\text { Physical Injuries } \\
\text { (i.e., Open } \\
\text { Wounds, Bruises) }\end{array}$ & $\begin{array}{l}\text { Fever } \\
\text { Measles } \\
\text { Skin Diseases }\end{array}$ & $\begin{array}{l}\text { Hypertension } \\
\text { Acute Malnutrition } \\
\text { Asthma } \\
\text { Diarrhea }\end{array}$ & $\begin{array}{l}\text { Psycho-social } \\
\text { Stress (i.e., mental } \\
\text { health issues, } \\
\text { gendered violence, } \\
\text { suicide) }\end{array}$ \\
\hline $\begin{array}{l}\text { Super } \\
\text { Typhoon }\end{array}$ & $\begin{array}{l}\text { Physical Injuries } \\
\text { (i.e., Bruises, burns) } \\
\text { Skin Problems (i.e., } \\
\text { Irritation) }\end{array}$ & $\begin{array}{l}\text { Dermatological } \\
\text { Problems } \\
\text { Measles } \\
\text { Respiratory Issues } \\
\text { Chikungunya } \\
\text { Chickenpox }\end{array}$ & $\begin{array}{l}\text { Heart Diseases } \\
\text { and Abnormalities } \\
\text { (i.e., Hypertension, } \\
\text { Cardiogenic Shock) } \\
\text { Malnutrition } \\
\text { Asthma } \\
\text { Acute Bloody Diarrhea } \\
\text { Dengue } \\
\text { Leptospirosis } \\
\text { Acute Hemorrhagic } \\
\text { Fever } \\
\text { Tetanus } \\
\text { Neonatal Tetanus }\end{array}$ & $\begin{array}{l}\text { Psycho-social } \\
\text { Stress (i.e., mental } \\
\text { health issues, } \\
\text { gendered violence, } \\
\text { suicide) }\end{array}$ \\
\hline $\begin{array}{l}\text { Volcanic } \\
\text { Eruption }\end{array}$ & $\begin{array}{l}\text { Physical Injuries } \\
\text { (i.e., Open } \\
\text { Wounds, Bruises) }\end{array}$ & Respiratory Issues & $\begin{array}{l}\text { Diarrhea } \\
\text { Heart Diseases } \\
\text { and Abnormalities } \\
\text { (i.e., Hypertension, } \\
\text { Cardiogenic Shock) }\end{array}$ & $\begin{array}{l}\text { Psycho-social } \\
\text { Stress (i.e., mental } \\
\text { health issues, } \\
\text { gendered violence, } \\
\text { suicide) }\end{array}$ \\
\hline
\end{tabular}

Table 3 offers a comparative juxtaposition of the four scenarios in terms of the long-term health effects of disasters on the afflicted population. The psychological trauma imprinted on certain population members can be as deep and persistent as the physical trauma caused by major natural disasters, depending on the magnitude and severity of the detrimental effects. However, various psycho-social issues such as PTSD, depression, and so on could occur after evacuation. According to the research, displacement situations at the relocation sites might result in the emergence of new cases of psychological difficulties.

Table 3. Long-term health impact of disasters

\begin{tabular}{ll}
\hline \multicolumn{1}{c}{ Case } & \multicolumn{1}{c}{ Psycho-social Problems } \\
\hline $\begin{array}{l}\text { Flooding } \\
\text { Earthquake } \\
\text { Super Typhoon } \\
\text { Volcanic Eruption }\end{array}$ & $\begin{array}{l}\text { Psycho-social Stress (i.e., PTSD, drinking behavior, depression, } \\
\text { suicide) }\end{array}$ \\
\hline
\end{tabular}

\section{Effectiveness in handling health consequences}

Flooding. The lack of a DRRM council in the city resulted in a disorganized reaction to Tropical Storm Washi's devastation. It lacked rescue and medical staff who were prepared to respond to an emergency. Furthermore, local authorities had to rely on several non-governmental groups in the area (Franta et al., 2016). The devastation of homes, as well as water and sanitation infrastructure, 
exposed communities to polluted water. More than thirteen thousand people were sent to different evacuation shelters (NDRRMC, 2012).

The Philippine government proclaimed a state of calamity in several districts three days following the passing of Washi. This proclamation opened the door for foreign groups to provide aid. A week after Typhoon Washi, the government took over recovery and rehabilitation efforts by establishing one-stop shops in the area.

Earthquake. In contrast to floods, which affect almost all communities in a particular area, earthquakes do not practically paralyze all communities. The 2013 earthquake may have killed more than ten people and wounded many others in Tubigon Municipality. However, more than forty thousand additional residents were able to mobilize in rescue and retrieval activities. Even though the earthquake destroyed government buildings, the local authority set up at least two evacuation shelters, provide basic needs to the evacuees for at least four days, and conduct a fast evaluation of the municipality's structural losses (Global Media Arts [GMA], 2013). However, the injuries on the infrastructures that connected the barangays inside the Tubigon itself and neighboring cities hindered disaster response. The food supply system was also affected as a result of the real damages. The earthquake wrecked the municipality's water infrastructure, necessitating the distribution of clean water to refugees and residents who chose to camp close to their broken homes or in various open spaces.

The provincial administration of Bohol proclaimed a state of calamity during the day that the earthquake struck. Government units and various international aid from different groups began to arrive. Tubigon Municipality's port provides an advantage for more efficient transport of products and services. All in all, more than six hundred families and eight thousand individuals were affected and flocked to various evacuation centers (NDRRMC, 2014b).

Super typhoons. Tacloban City severely overestimated the size of anticipated storm surges by failing to use the current storm surge danger map. It had permitted or tolerated numerous residents to build structures on risk zones for several years before the disaster. A large-scale tragedy resulted in so much mortality and devastated the disaster response system of the city due to such past lapses when combined with the issues and problems on the understanding of inhabitants on storm surges. As despair, thirst, and starvation set in, distribution of basic needs and city transportation systems fail. Furthermore, the police force, the health systems, and even public order were also problematic at the time.

The distribution of help from the national government was further delayed due to political wrangling. The widespread devastation forced more than nineteen thousand people to seek refuge in thirty evacuation sites, although a large amount of them chose to remain in temporary shelters close to their destroyed houses (WHO, 2013). Other residents chose to flee Tacloban City in a huge exodus, either temporarily or permanently. The Philippine government proclaimed a state of calamity in several Visayas areas three days after Haiyan hit. This circumstance allows the Philippine government to maintain jurisdiction and power over the impacted areas while also allowing foreign groups to assist. The next day, establishing a one-stop-shop assisted in receiving and processing aid from a huge range of local and international government and other institutions and organizations.

Volcanic eruptions. The slow-moving nature of the eruptions and its direct effect on a small area of the city makes the extreme event's aftermath simpler to manage. Albay Province and Legazpi City have become better competent in dealing with comparable calamities due to the lessons learned from the tragedy of the 1993 and 2006 eruptions. As far as the 2018 eruption is concerned, the well-coordinated evacuation tactics resulted in no deaths. Another is APSEMO's creation of a supportive local and global network of government. Other institutions and organizations are ready to help. The Philippine government proclaimed a state of disaster in the whole province two days after alert levels 2 and 3 were raised. This lawsuit paved the way for international help to arrive. The evacuation facilities' food supplies and medical treatment were sufficient. APSEMO followed its stringent practice of not allowing disaster victims or people at evacuation shelters to leave the premises. Furthermore, according to the International Federation of Red Cross and Red Crescent Societies (2018), malnutrition was not reported in the evacuation camps. Nevertheless, the local government entities were able to meet the health-related demands of the evacuees. 


\subsection{Synthesis and Conclusion}

The four disasters discussed in this study each have their unique topography. Cagayan de Oro and Tacloban attempt to address various geohazard issues through constructing enormous dikes and seawalls. The cities' efficacy will be determined once these massive projects are completed. Hazard maps must also be updated. It is necessary to identify and enforce no-build zones. The no-build and other risk zones in Legazpi City are outstanding since they are designated not just on maps but also on the real terrain of Mayon Volcano.

Politics also has a lot to do with disaster risk reduction and management. Politics was highlighted as one of the disaster's causes in Cagayan de Oro's case. Not only did the city's political authorities fail to police no-build zones, however, they also put numerous urban poor people in danger zones. In the instance of Tacloban, political wrangling between the city government and the Philippine government caused the Philippine government's rescue and response activities to be severely delayed. In the case of Tubigon Municipality, the administration was unsuccessful in conducting an audit of built structures to ensure compliance with the National Building and Structural Codes and to enact subsequent retrofitting or condemnation of non-compliant structures.

At both the local and national levels, awareness of the sort and magnitude of a disaster and planning for how to respond to such an occurrence are key elements. According to the research, local government bodies should depoliticize and professionalize councils handling disaster risk reduction management. Following the development of stable and developed DRRM councils in local governments, citizens may be informed and prepared via units of the community and maybe local mass communication channels.

This research has also established that the health effects of catastrophic disaster occurrences may be limited. However, when disaster response teams experience difficulties and dysfunction, these situations require special attention. Furthermore, the incomplete swing-based response at the community level exists between the onset of disaster and the point when the barangay should fill in the disaster operations at the local government levels.

This article described types of disaster-related short-term health consequences. The first are those that arose instantly due to extreme natural phenomena as a result of exposure to low temperatures and rainy weather. The second group arose from the environmental consequences of various disasters. The last factor is the protracted stay in sometimes substandard evacuation centers, leading to infections and even severe starvation. However, there is a need to reconsider long-term settlement in makeshift evacuation shelters for the third category.

Psycho-social issues are frequently the long-term health consequences of disasters. Three key aspects concerning these problems are discussed in this work. For starters, many of these issues arose due to the extended stay in evacuation shelters. Second, even after the decampment at the evacuation camps, certain mental issues may occur, especially if some residents are relocated. Lastly, the long-term psycho-social consequences of catastrophes are often unnoticeable and handled parts of response and recovery from extreme natural events.

The disaster risk reduction and management experiences and lessons of the case studies should be used to strengthen its preparations, plans, and protocols concerning disasters experienced. This can only happen if a local government unit of the particular city has a stable and professionalized council managing the risk of different disasters that can collect and integrate such a large amount of fresh information. These experiences and lessons learned by the four case studies might benefit other areas as well.

\section{REFERENCES}

Ballera, J., de los Reyes, V., Sucaldito, M., De Guzman, A., Sy, L., Avelino, F., Zapanta, M., Feliciano, J., \& Tayag, E. (2015). Management of the dead in Tacloban City after Typhoon Haiyan. Western Pacific surveillance and response journal, 6 (Supplement 1), 44-47. https://doi.org/10.5365/wpsar.2015.6.2.hyn_004

City of Tacloban. (2016). Awards. http://tacloban.gov.ph/about/awards/\#.XCSV6VUzZOw.

Curato, N. (2018). Beyond the spectacle: Slow-moving disasters in post-Haiyan Philippines. Critical Asian Studies, 50 (1), 58-66. https://doi.org/10.1080/14672715.2017.1407249

Czaicki, A. E., Fabrigas, G., Gocotano, A., \& Hall, J. L. (2015). Is my drinking a problem? A community-based alcohol intervention programme post-Haiyan in Tacloban City. Western Pacific Surveillance and Response Journal: WPSAR, 6(Suppl 1), 96. https://doi.org/10.5365/wpsar.2015.6.2.hyn_016 
Dreher, J., \& Santos, H. (2017). Sociology and Phenomenology. Civitas - Revista de Ciências Sociais, 17(3), 385-388. https://doi.org/10.15448/1984-7289.2017.3.29429

Franta, B., Roa-Quiaoit, H., Lo, D., \& Narisma, G. (2016). Climate disasters in the Philippines: a case study of immediate causes and root drivers from Cagayan de Oro, Mindanao and Tropical Storm Sendong/Washi. Belfer Center for Science and International Affairs, Cambridge, MA: Harvard University.

Global Media Arts (GMA). (2013). Unang Balita: Bayan ng Tubigon, Bohol, isa sa may pinakamaraming evacuees. Youtube. https://www.youtube.com/watch?v=yBauFm0stw0.

Goodrick, D. (2014). Comparative case studies: Methodological briefs-impact evaluation no. 9 (No. innpub754). https://ideas.repec.org/p/ucf/metbri/innpub754.html

International Federation of Red Cross and Red Crescent Societies. (2018). Philippines: Mayon Volcano information bulletin number 1 to 3 (Final). Reliefweb. https://reliefweb.int/report/philippines/philippines-mayonvolcano-information-bulletin-n-1.

La Viña, A., \& Berse, K. (2013). Lessons from the Bohol disaster. Rappler. https://www.rappler.com/thoughtleaders/41766-lessons-bohol-disaster-part-1.

Luces, K. (2013). A history of storms: 1890s newspaper reveals devastating Leyte typhoon. https://www.gmanetwork. com/news/scitech/science/335673/a-history-of-storms-1890s-newspaper-reveals-devastating-leytetyphoon/story/.

McCall, C. (2014). Scars of typhoon Haiyan still run deep one year on. The Lancet, 384 (9955), 1656-1657. https:// doi.org/10.1016/S0140-6736 (14)62019-5

National Disaster Risk Reduction Management Council (NDRRMC). (2012). Situational report number 47: Effects of tropical storm "Sendong" (Washi) and status of emergency response operations. National Disaster Risk Reduction Management Council. http://www.ndrrmc.gov.ph/attachments/article/1809/ SitRep_No_47_re_effects_of_tropictr_Storm_SENDONG_and_Status_of_Emergency_Response_Operations_as of_26JAN2201_0800H.pdf.

National Disaster Risk Reduction Management Council (NDRRMC). (2014a). Situational Report Number 108: Effects of Typhoon "Yolanda" (Haiyan. http://www.ndrrmc.gov.ph/attachments/article/1329/SitRep_No_108_Effects_ of_TyphooT_Yolanda_HAIYAN_as_of_03APR2014_0600H.pdf.

National Disaster Risk Reduction Management Council (NDRRMC). (2014b). Situational report number 33: Re effects of magnitude 7.2 Sagbayan, Bohol earthquake. Reliefweb. https://reliefweb.int/disaster/eq-2013000134-phl?page =13\# content.

Neussner, O. (2014) Assessment of early warning efforts in Leyte for typhoon Haiyan/Yolanda. Manila: Deutsche Gesellschaft für Internationale Zusammenarbeit. https://www.preventionweb.net/ files/36860_36860gizassessmentofearlywarningyol.pdf.

Orense, R.P., \& Ikeda M. (2007). Damage caused by typhoon-induced lahar flows from Mayon Volcano, Philippines. Soils and foundations, 47(6), 1123-1132. https://doi.org/10.3208/sandf.47.1123

Philippine Institute of Volcanology and Seismology (PHIVOLCS). (2017). Mayon Volcano hazard maps.

Philippine Institute of Volcanology and Seismology (PHIVOLCS). (2018). Mayon Volcano alert signals. https://www. phivolcs.dost.gov.ph/index.php/volcano-hazard/volcano-alert-level.

World Health Organization (WHO). (2013). Typhoon Yolanda health cluster bulletin, issue number 1 to 18. Reliefweb. https://reliefweb.int/disaster/tc-2013-000139-phl?page=190\#content.

\section{Correspondence:}

EXALTACION E. LAMBERTE

exaltacion.lamberte@dlsu.edu.ph

FEORILLO PETRONILLO A. DEMETERIO III

feorillo.demeterio@dlsu.edu.ph

https://orcid.org/0000-0003-1191-971X

WILFRED LUIS L. CLAMOR

wilfred.clamor@dlsu.edu.ph

https://orcid.org/0000-0003-4672-4250 